\title{
Study the Consumption Pattern of Milk and Milk Products along with Animal Foods in Kumaon Region of Uttarakhand, India
}

\author{
Savita Kumari ${ }^{1}$, Kalpana Kulshrestha ${ }^{2}$, Jitendra Prasad ${ }^{1}$, \\ Ranjan Kumar ${ }^{1}$ and S. Shekhar ${ }^{3 *}$
}

\author{
${ }^{1}$ Krishi Vigyan Kendra, Saraiya, Muzaffarpur Bihar-843126, India \\ ${ }^{2}$ College of Home Science, GBPUA \& T Pantnagar, Uttarakhand, India \\ ${ }^{3}$ Krishi Vigyan Kendra, Jainagar (ICAR-NRRI), Koderma, Jharkhand, India
}

*Corresponding author

\section{Keywords}

Consumption trends, Frequency of

consumption, Routinely

consumption, Milk and

Milk products, Animal

foods

Article Info

Accepted:

04 March 2018

Available Online:

10 April 2018

\section{A B S T R A C T}

This study was an attempt to present the comprehensive picture of trends in consumption of milk and milk products along with animal foods such as meat, fish, poultry and eggs in Kumaon region of Uttarakhand. Milk and milk products were one of the main items in the meal of people of Kumaon region. Its routinely consumption was as high as among $82 \%$ population for milk during 1950 but the reduction in frequency of milk and curd consumption among 55 year and above age group was from $82 \%$ population to $48 \%$ of population and $64 \%$ population to $30 \%$ of population respectively from 1950 to 2000 onwards. The reduction in routinely/daily consumption of butter milk was much more, which reduced from 57\% population in 1950 to $7 \%$ population in 2000 onwards. Ghee also occupied major place in the meal of elderly and $81 \%$ population were using it routinely which was continue in next decade also. But its consumption percentage started to sharply decrease from 1990 and reached to nearly 38\% after 2000 onwards. Age groups between 35 - 55 and 15 - 35 were also using these products but their routinely consumption was lesser in compare to elderly population (55 year and above age group). Likewise routinely butter consumption decreased sharply from 33\% to $4 \%$ among elderly and $22 \%$ to $5 \%$ for $35-55$ year age group and $12 \%$ to $2 \%$ for 15 -35 age group. Routinely consumption of flesh food was negligible among 55 years and above age groups and 15-35 year age groups.

\section{Introduction}

Food consumption pattern provide valuable information about the nutritional and health status of individual. Technological advancement in food science has entirely changed the traditional healthy consumption pattern of meal by different age groups. This invites lots of health and nutritional problems.
As most people of Uttarakhand were vegetarian and milk is known as one of the complete food so consumption of milk and milk products play a very important role in keeping the people sound and healthy. Previously milk and its different products were used as only the source of beverage and sweets. Milk, tea, butter milk, lassi etc., were one of the main beverages which were entirely 
losing its place and substituted by soft drink, cold drink, chocolate drink, beer, wine etc. Likewise it was the basic item of many sweets in form of khoa, chenna and ghee. So an attempt is made to encourage the consumption of these nutritious products for which the study of consumption pattern of these products in previous decade was conducted.

\section{Materials and Methods}

Present study was conducted in three districts namely Udham Singh Nagar, Nainital and Champawat of Kumaon region of Uttarakhand for study on the basis of food insecurity status. From each district two blocks and from each block two rural and two urban areas were selected for study (Table 1). Nearly twelve families were taken from each area. Total 142 families representing different socio-economic status were selected for study. The study comprised of male and female between the age group of 55 year and onwards. Selection of respondents was done by using snow ball sampling method.

\section{Results and Discussion}

Routinely consumption of milk and milk products shows that percent of population (55 years and above age groups) consuming milk, curd and buttermilk was almost same from 1950-70. After 1980 the reduction in consumption was more distinct. The reduction in frequency of milk and curd consumption was from $82 \%$ to $48 \%$ population and $64 \%$ to $30 \%$ population respectively from 1950 to 2000 onwards. The reduction in butter milk was much more, which reduced from $57 \%$ population in 1950 to $7 \%$ population in 2000 onwards. Consumption of paneer on daily basis was zero percentage. Trends of surplus use of milk and milk products was in culture of Uttarakhand and study done by Bohra et al., (2004) shows that average amount of milk retained at peri-urban farms (Champawat district) actually amounts to per capita per day milk consumption, which is $492 \mathrm{ml}$ i.e., 242 $\mathrm{ml}$ higher than the recommended amount. Out of the total milk consumed per day, about $1861 \mathrm{ml}(60 \%)$ is consumed directly by family members of different age groups. Some amount of milk (771 $\mathrm{ml}$ or $25 \%)$ is consumed through tea. The remaining $450 \mathrm{ml}(15 \%)$ per farm is consumed after being converted into other dairy products. National Family Health Survey (NFHS -2 and NFHS-3) conducted in 1998-99 and 2005-06 also showed reduction in frequency of daily consumption of milk or curd in Uttarakhand. Deaton et al., (2009) states that buttermilk widely available often free of cost, in many villages of India, particularly in the north-western region. In those days, large quantities of buttermilk were available as a by-Product of ghee, butter and other local milk products. With the growing commercialization of milk, these local processing activities have declined, and so has the availability of buttermilk. Routinely consumption of milk, curd and buttermilk, in 1960-70 were among $82 \%, 63 \%$ and $55 \%$ population (35-55 years age groups) respectively. Less than $1 \%$ were consumed channa. The consumption of milk, curd, buttermilk and channa progressively decreased to $47 \%, 40 \%, 11 \%$ and $0.47 \%$ population respectively after 2000. Maximum percentage of population (15-35 age groups) was routinely consumed milk and milk products (curd and buttermilk) during 1980-90. Routinely consumption in frequency of milk, curd and buttermilk was $78 \%, 61 \%$ and $30 \%$ respectively, which decreased continuously decade wise to $52 \%, 38 \%$ and $11 \%$ after 2000. Routinely consumption of pure ghee mostly prepared at home was very common in early fifties to seventies. $80 \%$ population (55 years and above) were consumed ghee daily in different forms as, spread on chapatti / seasoning of dal / sweet dish preparation / use in deep frying puri etc. The routinely consumption frequency progressively 
decreased from $81 \%$ in 1950 to $38 \%$ population after 2000, whereas monthly, fortnightly, weekly and 2-3 days in a week consumption progressively increased. People who never consumed ghee increased from 5\% in 1950 to $19 \%$ in 2000 onwards. Similar trend in consumption pattern of ghee was found by Bohra et al., (2004). In peri- urban villages of Lohaghat block of Champawat district, milk not to be consumed directly at home was converted in butter, which is later on refined into ghee. Almost entire ghee produced at a peri-urban farm was consumed. Practice of selling ghee was rare. Routinely consumption of ghee was very common during 1960-70 and $72 \%$ populations (35-55 years) were consuming it but it's routinely consumption continuously decreased to $43 \%$ population after 2000. Frequency of consumption other than routinely increased from 1960-70 and percent percentage of population never consuming doubled after 2000 in comparison to 1960-70. More than $50 \%$ population (15-35 years) was consuming ghee on routinely basis since 1980, in which maximum population was during 1980-90 followed by 1990-2000 and 2000 onwards. During 1980-90, only $1 \%$ was not taken ghee which increased to nearly $11 \%$ after 2000 . Percentage of population (55 years and above) consumed butter (mostly homemade) was roughly ten times more in 1950-60 as compared to 1990 onwards. $33 \%$ people were consumed it routinely which sharply decreased after 1970 and reached to $4 \%$ in 1990. Percentage of people consuming it weekly and 2-3 days in a week was also maximum in 1950-60 and minimum after 1990 onwards. Processing of milk not to be consumed directly at home is converted into butter. About half of the butter is consumed and the remaining is refined into ghee at all dairy farms (Bohra et al., 2004). During 1960$70,42 \%$ of population (35-55 years) was consuming mainly homemade butter at least once in a week and $22 \%$ were consuming daily. The percentage of population consuming butter at least once in a week reduced to $15 \%$ population after 2000 in which only $5 \%$ were consuming it daily. Generally homemade butter was used in Kumaon region, and it's routinely consumption percentage (15-35 years) decreased sharply after 1990 in comparison to 1980-90. Nearly $12 \%$ population was consuming it during eighties which decreased to $2 \%$ after 2000 . Weekly and 2-3 days in a week consumption was nearly same throughout the decades. Percentage of population (55 years and above) consuming butter (mostly homemade) was roughly ten times more in 1950-60 as compare to 1990 onwards. About $33 \%$ people were consuming it routinely which sharply decreased after 1970 and reached to $4 \%$ in 1990 . Percentage of people consuming it weekly and 2-3 days in a week was also maximum in 1950-60 and minimum after 1990 onwards. Processing of milk not to be consumed directly at home is converted into butter. About half of the butter is consumed and the remaining is refined into ghee at all dairy farms (Bohra et al., 2004). During $1960-70,42 \%$ of population (35-55 years) was consuming mainly homemade butter at least once in week and $22 \%$ were consuming daily. The percentage of population consuming butter at least once in week reduced to $15 \%$ population after 2000 in which only $5 \%$ were consuming it daily. Generally homemade butter was used in Kumaon region, and it's routinely consumption percentage (15-35 years) decreased sharply after 1990 in comparison to 1980-90. Nearly $12 \%$ population was consuming it during eighties which decreased to $2 \%$ after 2000 . Weekly and 2-3 days in week consumption was nearly same throughout the decades. Less than $50 \%$ people (55 and above age groups) consumed flesh food in Kumaon region. The consumption rate was decreasing as the age advanced. 
Table.1 Areas selected for the study the consumption pattern of milk, Milk product and animal foods

\begin{tabular}{|c|c|c|c|c|}
\hline Region & District & Blocks & Urban areas & Rural area \\
\hline \multirow{6}{*}{$\begin{array}{l}\text { Kumaon of } \\
\text { Uttarakhand, } \\
\text { Indian }\end{array}$} & \multirow[t]{2}{*}{$\begin{array}{l}\text { Udham } \\
\text { Singh Nagar }\end{array}$} & Rudrapur & $\begin{array}{l}\text { Adarshnagar and } \\
\text { Awas Vikas }\end{array}$ & $\begin{array}{l}\text { Shantipur and } \\
\text { Jawaharnagar }\end{array}$ \\
\hline & & Kashipur & $\begin{array}{l}\text { New Awas Vikas } \\
\text { and Awas Vikas }\end{array}$ & $\begin{array}{l}\text { Himmatpur and } \\
\text { Hempur Ismail }\end{array}$ \\
\hline & \multirow[t]{2}{*}{ Nainital } & Haldwani & $\begin{array}{l}\text { Haldwani ward } \\
\text { no. } 19 \text { and ward no. } 7\end{array}$ & $\begin{array}{l}\text { Tallibamori and } \\
\text { Quality colony }\end{array}$ \\
\hline & & Bhimtal & $\begin{array}{l}\text { Mallital ward no. } \\
\text { and ward no. } 2\end{array}$ & $\begin{array}{l}\text { Bhujiaghat and } \\
\text { Bhalutia }\end{array}$ \\
\hline & \multirow[t]{2}{*}{ Champawat } & Lohaghat & $\begin{array}{l}\text { Hatrangia and } \\
\text { Bajarangbali ward }\end{array}$ & $\begin{array}{l}\text { Kaligaon and } \\
\text { Chaurigaon }\end{array}$ \\
\hline & & Champawat & $\begin{array}{l}\text { Mallihatt ward no. } 2 \\
\text { and Sellakulla }\end{array}$ & $\begin{array}{l}\text { Kharak Karki and } \\
\text { Mali Madli }\end{array}$ \\
\hline
\end{tabular}

In 1950 the percentage of people not consuming flesh food was $53 \%$ which increased to $67 \%$ in 2000 onwards. Most of the non-vegetarians were taking flesh food weekly or fortnightly. Only $0.7 \%$ people in 1960-80 were taking flesh food daily. Weekly and 2-3 days in week consumption was $18 \%$ and $9 \%$ population in 1950 which decreased to $8 \%$ and $3 \%$ population respectively in 2000 onwards.

The fortnightly consumption was progressively increased from 1950-1990 and again decreased as age advanced. The monthly consumption was mostly same throughout the year. Trend of less consumption of flesh food is shown by NFHS-2 (1998-99) data, which in Uttarakhand the daily and weekly consumption of chicken, meat or fish was only $2.3 \%$ and $12.5 \%$ respectively, which was decreased to $0.7 \%$ and $9.5 \%$ in $2005-06$ (NFHS-3). People never ate flesh food also increased from $39.9 \%$ in $1998-99$ to $43.1 \%$ in 2005-06. Tandon et al., (1972) also found same type of food habits. Decrease in consumption percentage among elderly was seen in NNMB, report on diet and nutritional status of elderly by Vijayaraghavan et al.,
(2000), where consumption of flesh food other than fish was decreased in all elderly people (60-80) from 4 gm per day in 1975 -79 to $2 \mathrm{gm}$ per day in 1996-97. In Kumaon region more than 50\% people (35-55 age groups) were not consuming flesh food since 1950 to 2000 onwards. Maximum population was consuming it weekly followed by fortnightly, monthly and $2-3$ days in a week. Weekly, fortnightly and 2-3 days in a week consumption decreased continuously from $19 \%, 13 \%$ and $8 \%$ population during $1960-70$ to $16 \%, 8 \%$ and $5 \%$ population respectively after 2000 .

Monthly consumption increased from 8\% population during $1960-70$ to $10 \%$ population after 2000. Flesh food was mostly consumed on weekly basis and there was no more decade wise difference in 15-35 age groups. During 1980-90, 17\% were consuming flesh foods on weekly basis which decreased to $16 \%$ after 2000. Consuming 2-3 days in a week was among $8 \%$ people during eighties and decreased to $5 \%$ after 2000 . Monthly and fortnightly consumption also decreased from $10 \%$ and $11 \%$ respectively. Egg consumption was only among $26 \%$ population (55 and above age groups) in 1950-60 and frequency 
of consumption ranged from monthly to 2-3 days in a week. No one was taken it routinely. The percent of people consuming egg increased to $35 \%$ population after 1970 and again started to decrease after 1990 as age advanced. The percent of people consuming egg again reached to $28 \%$ population after 2000. The routinely consumption of egg was among $2 \%$ population especially in winter season. According to NFHS-2 survey only $1.7 \%$ women in Uttarakhand were consumed egg daily and $10.8 \%$ were taken it weekly in 1998-99. The daily consumption was increased among $2.3 \%$ women and $2.7 \%$ in men in 2005-06. ICMR report on noncommunicable disease risk factor survey 2007-08, reported that in Uttarakhand, $2.5 \%$ people were consuming egg daily and $24.8 \%$ people were taking it at least once in a week. Only $30 \%$ to $45 \%$ population (35-55 age groups) was consuming egg. Routinely and 2 3 days in a week consumption was only among $1.68 \%$ and $2.52 \%$ population during 1960-70 which increased to $3.77 \%$ and $8 \%$ population respectively after 2000 . Weekly consumption increased from $13 \%$ in early years to $19 \%$ after 1990 and then decreased little to $18 \%$ population. Weekly and fortnightly consumption was among $4 \%$ to 9\% population. Egg was mostly consumed (15-35 age groups) on weekly basis followed by 2-3 days in a week and fortnightly basis. Weekly, 2-3 days in a week and routinely consumption increased after 2000 and 22\%, $20 \%$ and $2 \%$ were consuming egg respectively. People not consuming egg decreased from $45 \%$ during $1980-90$ to $36 \%$ after 2000.

\section{References}

Bohra, B., Singh, M., Kumar, A. and Singh, V. 2004. Milk production, marketing and consumption pattern at peri-urban dairy farms in the mountains: a case from Lohaghat in Uttaranchal. ENVIS Bulletin: Himalayan Ecology. 12(1): 30-37.

Deaton, A. and Jean, D. 2009. Food and Nutrition in India: Facts and Interpretations February 14, EPW Economic \& Political Weekly, X liv. (7): 42-65.

National Family Health Survey (NFHS-2) India 1998-99. Uttaranchal IIPS and ORC Macro. 2002:

National Family Health Survey (NFHS-3), India, 2005-06. Uttarakhand. Mumbai: IIPS. 2008 www.nfhsindia.org/ uttarakhand_repirt.pdf. Accessed on 3. 9.2011

Tandon, B.N., Ramchandran, K., Sharma, M.P. and Vinayak, V.K. 1972. Nutritional survey in rural population of Kumaon hill areas, North India. The American Journal of clinical Nutrition. 25: 432-436.

Vijayaraghavan, K., Balakrishna, N. and Antony, G. M. 2000. Report on food and nutrient intakes of individuals. NNMB Technical report No. 20.

Vijayaraghavan, K., Venkain, K., Damayanti, K. and Umanayak, M.2000. Report on diet and nutritional status of adolescent. NNMB Technical Report No. 20.

\section{How to cite this article:}

Savita Kumari, Kalpana Kulshrestha, Jitendra Prasad, Ranjan Kumar and Shekhar, S. 2018. Study the Consumption Pattern of Milk and Milk Products along with Animal Foods in Kumaon Region of Uttarakhand, India. Int.J.Curr.Microbiol.App.Sci. 7(04): 250-254. doi: https://doi.org/10.20546/ijcmas.2018.704.028 